University of Nebraska - Lincoln

DigitalCommons@University of Nebraska-Lincoln

1920

\title{
THE ENGLISH BALLADS AND THE CHURCH
}

Louise Pound

Follow this and additional works at: https://digitalcommons.unl.edu/englishfacpubs

Part of the Comparative Literature Commons, English Language and Literature Commons, Modern Literature Commons, and the Reading and Language Commons

This Article is brought to you for free and open access by the English, Department of at DigitalCommons@University of Nebraska - Lincoln. It has been accepted for inclusion in Faculty Publications -Department of English by an authorized administrator of DigitalCommons@University of Nebraska - Lincoln. 


\title{
PUBLICATIONS
}

OF THE

\section{Modern Language Association of America}

\author{
1920
}

VoL. $\mathrm{XXXV,2}$

New Series, Vol. XXVIII, 2

\section{IX.-THE ENGLISH BALLADS AND THE CHURCH}

Many origins have been suggested for the type of narrative song appearing in the English and Scottish traditional ballads: minstrel genesis, origin in the dance, improvisations of mediæval peasant communes, or descent from the dance songs of primitive peoples. The hypothesis of minstrel origin was that first to be advanced and it has always retained supporters. There remains a possibility not yet brought forward which deserves to be presented for what it is worth, since the problem, though it may be insoluble, has its attraction for critic and student. We have but meager knowledge of the ballad melodies of pre-Elizabethan days, and we can get but little farther with the study of the ballads by way of research into mediæval music. Moreover the earliest texts remaining to us seem to have been meant for recital rather than for singing. In general, the melodies of ballads are more shifting, less dependable, than are the texts, in the sense 
of the plots and the characters which the texts present. This is true of contemporary folk-songs and it was probably true earlier. One text may be sung to a variety of airs or one air may serve for many texts. Nor can we get much farther with the study of ballads by way of the minstrels. They have had much attention already; and nothing has ever been brought out really barring them from major responsibility for ballad creation and diffusion in the earlier periods. Again, we can get but little farther by studying the mediæval dance, or folk-improvisations, or the dance songs of primitive peoples, all of which have been associated with the Child ballads to an exaggerated degree. It is time to try a new angle of approach-the last remaining-although the hypothesis which it suggests is far removed from the theory of genesis enjoying the greatest acceptance at the present time, and although it-like its predecessors-may not take us very far.

It has been customary among theorizers completely to discard the chronological order of the ballad texts remaining to us, and to argue toward origin and development from a type of ballad like Lord Randal and Edward, of comparatively late appearance, when such reversal of chronology best suited the theory to be advanced. The contrary procedure, theorizing from the facts of chronology, is the logical one. If the ballad texts which are oldest are given attention and emphasis, actual fact adhered to and conjecture omitted, can anything distinctive be reached? This method of approach is one to which the ballads have never been subjected in more than a cursory way. If it is tried, in what direction does it lead? 
The Earliest Ballad Texts

If we accept the body of English and Scottish ballad material as defined by Professor F. J. Child, the oldest ballad texts existing have to do rather strikingly with the church. They have unmistakably an ecclesiastical stamp, and sound like an attempt to popularize Biblical history or legend. By our oldest texts are meant those to be found in early manuscripts of established date, not texts recovered from an oral source or found in manuscripts of later centuries. ${ }^{1}$ The earliest remaining English ballad is conceded to be the Judas, a narrative of 36 lines in rhyming couplets, which endows him with a wicked sister, refers to his betrayal of Christ for thirty pieces of silver, and reflects some of the curiosities of mediæval legend concerning him. ${ }^{2}$ The manuscript preserving it, in the library of Trinity College, Cambridge, is certainly of the thirteenth century. The same manuscript contains A Ballad of the Twelfth Day, a ballad of the same general nature as the $J u d a s$ and written in the same hand. ${ }^{3}$ It has probably escaped general recognition as a ballad because composed in monorhyme quatrains, a more elaborate form, instead of in the couplets of the Judas.

From the fifteenth century comes Inter Diabolus et

${ }^{1}$ For the dating of ballad texts, see E. Flügel, Zur Chronologie der englischen Balladen, Anglia, vol. XXI (1899), pp. $312 \mathrm{ff}$.

'Compare P. F. Baum, "The English Ballad of Judas Iscariot," Publications of the Modern Language Association of America, vol. XXXI (1916), p. 181, and "The Mediæval Legend of Judas Iscariot," ibid., p. 481.

${ }^{3}$ Printed, with editorial notes, by W. W. Greg, The Modern Language Review, vol. vIII, p. 64, and vol. IX (1913), p. 235. 
Virgo, ancestor of many riddling ballads, preserved in the Bodleian library at Oxford, a piece in which the devil is worsted by a clever and devout maiden. The questions and answers reach their climax in "God's flesh is better than bread" and "Jesus is richer than the King." Likewise from the fifteenth century is St. Stephen and Herod, in the Sloane manuscript of about the middle of the century, which incorporates the widespread mediæval legend of the cock crowing from the dish Cristus natus est, a legend which appears also in the well-known carol or religious ballad, The Carnal and the Crane. Als I yode on a Mounday, in 8-line stanzas, preserved in a fourteenthcentury manuscript in the Cotton collection, is hardly a ballad, but a poem to which the later ballad, The Wee Wee Man, may be related. It is not admitted among ballads by Professor Child. Thomas Rymer is generally accounted old, since its hero is Thomas of Erceldoune; we do not have it, however, in early form, but from the eighteenth century, and there is no determining the time of its composition. There is a fifteenth-century poem, in ballad stanza, Thomas of Erseldoune, preserved in the Thornton manuscript, but it is usually classified as a romance or a romantic poem, never as a ballad. The existing ballad, on the same theme, is probably not a legacy from the romance, but an independent creation telling the same story. Possibly it is based on the romance. Among earlier texts are left, then, only a few greenwood and outlaw pieces from no farther back than the middle of the fifteenth century. The first is Robin and Gandeleyn, a greenwood ballad from about 1450, which opens in the reporter's manner of so many of the chansons d'aventure:-

I herde the carpynge of a clerk $\mathrm{Al}$ at yone wodes ende. 
Others are Robin Hood and the Monk (which has a reverdi opening), Robin Hood and the Potter of about 1500, and $A$ Gest of Robin Hood of perhaps a few years later. There were earlier songs and rhymes, just as there were later songs and rhymes of Robin Hood, ${ }^{4}$ but whether he was celebrated in the ballad manner prior to the fifteenth century we do not know. ${ }^{5}$ The ecclesiastical pieces are in the couplet form usually recognized by scholars as the older for ballads, while Robin and Gandeleyn and the Robin Hood pieces are in the familiar four-line stanza which became the staple ballad stanza. We should, very likely, go somewhat earlier than the thirteenth-century Judas for the genesis of the lyric type which it represents; but there is no doubt that, in respect to chronological appearance, our oldest ballads deal not with themes of love, romance, domestic tragedy, adventure, chronicle, or even outlawrythough the latter come as early as the fifteenth centurybut instead are strikingly ecclesiastical.

It need hardly be pointed out that this scrutiny is a logical one to make, though it would be idle to think its results decisive. It seems to suggest that the ballad as a

\footnotetext{
"Like the "rhymes" of Robin Hood mentioned in Piers Plowman.

5 The music of some of the Robin Hood songs, sometimes at least, seems to have been church music, or music of the same type. See a passage on "pryksong" in the Interlude of The Four Elements, dated by Schelling about 1517. (Halliwell edition, Percy Society Publications, 1848, pp. 50, 51.) See also pricksong in The Oxford Dictionary. There should be nothing surprising in the singing of ballads to music of ecclesiastical type, if such was the case. In contemporary folk-song, hymn tunes are constantly utilized, in the United States and elsewhere-as in the Faroe Islands, according to Thuren. The words of John Brown, in the period of the Civil War, were put together to a popular Methodist camp-meeting tune. Jean Beck (La Musique des Troubadours, Paris, 1910, pp. 19-24) leans to the opinion that the source of troubadour music, hence of Romance lyric poetry in general, is to be found in the music of the church.
} 
poetic type, a story given in simple lyrical or singable form, may have received impetus from, or have been evolved through the desire to popularize a scriptural story or legend. In other words, it is as though the ballad, like the religious carols and the miracle plays and a great mass of ecclesiastical lyrics and narrative poetry, might be a part of that great mediæval movement to popularize for edifying reasons biblical characters and tales, a movement having its first impulse in the festival occasions of the church. Then, again like the drama, it passes from ecclesiastical hands, with edification the purpose, into secular hands, with the underlying purpose of entertainment. To follow farther the possibilities, once the type was popularized and mainly in the hands of the minstrels, as the drama passed into the control of the guilds, a variety of material was assimilated, and (still like the drama) the religious material, having historically initial place, became submerged and ultimately well-nigh lost to view. The minstrels of great houses sang of the martial deeds of those houses, as of the Percys, the Stanleys, the Howards. ${ }^{6}$ Popular outlaws were celebrated, though in a somewhat upper-class way, in the Robin Hood pieces, in the period when outlaws were popular figures in literature; while for the entertainment of aristocratic mixed audiences, for which so many of the literary types of the Middle Ages were developed, all kinds of material, romantic and legendary and the like, were utilized. In its period of full development, the ballad shades off into many types, the epic chanson in Robin Hood, the allegory in The Rose of England, the verse chronicle in The Battle of Otterbourne, the romance in Sir Aldingar and Earl Brand, the aube in The

${ }^{\circ}$ In The Hunting of the Cheviot; The Rose of England and Flodden Field; Sir Andrew Barton. 
Gray Cock, the lament in Johnny Campbell, the carol in The Cherry Tree Carol, and theological discussion in verse in The Carnal and the Crane. ${ }^{7}$ The ecclesiastics and the minstrels, between them, were responsible for all or nearly all the new types of mediæval poetry, and (possibly enough) for the ballads too. ${ }^{8}$ Another illustration of the passing of an ecclesiastical mode into secular hands, is the Mary worship of the church, which was secularized in Provençal poetry and crossed to England in the woman worship of the chivalric code, reflected in the romances and the romantic lyrics.

"Other "literary" features of the ballads, the popular spring morning (reverdi) opening of the outlaw pieces and the frequent chanson d'aventure opening, were mentioned in connection with the discussion of fifteenth-century texts.

${ }^{8}$ If ecclesiastical ballads are the earliest ballads, The Carnal and the Crane, a theological discussion between birds of the type liked. in the Middle Ages, in which the Crane instructs her interrogator on the childhood and life of Jesus and in several apocryphal incidents, might be a ballad of earlier type than Lord Randal. Though itself first recorded in an eighteenth-century text, this ballad-carol has unmistakably early affiliations, as with St. Stephen and Herod, and early legendary matter concerning Christ. And the ballads Dives and Lazarus, traceable to the sixteenth century, The Maid and the Palmer of the Percy Manuscript, and Brown Robin's Confession of Buchan's collection, might represent an older type of material than Edward or Babylon. But this is purely speculative, and of no value as argument.

The ballad Hugh of Lincoln, or The Jew's Daughter, which still has vitality, though its earliest texts come from the middle of the eighteenth century, takes us back in its tragic story and its discovery of murder by miracle to the thirteenth century. The story of Hugh of Lincoln first appears in The Annals of Waverley, 1255, and in Matthew of Paris. It has parallels in the twelfth century and a cognate in Chaucer's The Prioresse's Tale. Hugh of Lincoln refers us to an old story of definite date more certainly than do most of the ballads. It deserves mention among those exhibiting, it would appear, material of older type than the outlaw, chronicle, or roman. tic ballads. 
It is certain that the earliest ballad texts do not sound as though they ever had any connection with the dance. Religious material sometimes appeared in mediæval dance songs, but it was the rarest of the many types of material found in such songs. ${ }^{9}$ There are traces of sporadic connection between the church and liturgical dancing in the Middle Ages, but established or widespread liturgical dancing is extremely doubtful. Testimonies are too abundant as to the stand taken by the mediæval church against dancing, whether by professional dancers or by the folk.

The application of the name "ballad," which means dance song, to the traditional lyric-epic did not come in a specific way until the eighteenth century; hence an etymological argument from the name, as indicating a dance origin for the species, should have no weight. A "ballad" in the fourteenth century was usually the artificial species which we now call the "ballade," a species which is to be associated with the dance. The name which we have fixed upon for them is perhaps responsible for our long association of the English and Scottish type with the dance, and for our refusal to look elsewhere for its genesis. In a manner exactly parallel, the word carol was applied late to religious songs of the Nativity and of Christmas (French noëls). When the word carol first appeared in English it meant a secular dance song of spring and love. We name religious songs of Christmas by a word that first meant dance song, as we do our traditional lyric-epics in verse. But for the definite suggestion of their name, it might seem less surprising that our earliest ballad texts associate themselves with biblical edification, not with dancing throngs on the village green.

There are no earlier ballad documents in other countries

• Böhme, Geschichte des Tanzes (1888), pp. $244 \mathrm{ff}$. 
than in England, so that the chronology of the ballad's appearance is the only certain test that we have concerning the time of composition of a ballad text. The age of the story or theme of a ballad and the age of the ballad itself may be quite different matters. Besides, not all nations show a liking for ballads. The South African Dutch are said to have folk-tales, but no ballads. Italian folk-song, except in the extreme north, had no ballads, and French folk-song has no such wealth of ballad poetry as English has. Some parts of Spain have no ballads. The Danish ballads are those most closely related to the English. The oldest Danish manuscript collection of ballads comes from about 1550 , although there are fragments of ballads and references to ballads which take us back somewhat earlier. One not very significant ballad, Ridderen $i$ Hjorteham, is of about 1450. A systematic examination of Scandinavian ballads from the angle of approach of the rôle played by ecclesiastical material or by ecclesiastical agents of composition and diffusion, might have some bearing for or against the conjectures of the present paper; but probably it would yield little or nothing decisive. Also to be desired is an investigation of the religious narrative lyric for Old French popular verse, since the mediæval English lyric owes so much to French sources.

The terminus a quo for ballad origin must be the beginning of the twelfth century. Ballads of the rhyming form of the English and Scottish type cannot in origin antedate the Norman Conquest. If the Anglo-Saxons had ballads they were of the character of Old Teutonic verse, in some respects like the Brunanburh song, or the Battle of Maldon, or possibly like some of the Charms; in any case they were not in the rhyming form of the later ballads, the lyrical type which is under discussion here. The musical pliability of the lyric came from the south, across the 
Channel, modifying the stubbornness of the Old Northern verse and its sameness of movement. Some old lore may have been handed on into the rhymed forms, old wine passing into new bottles, but the old song modes made way in general for the newer. Ballads of the rhyming Child pattern must have arisen, like modern poetry and prosody in general, after 1100. We have one ballad, Judas, and possibly a second, A Ballad of Twelfth Night, from the thirteenth century; and in general from 1200 onward much popular verse remains. It would help if more remained, but we need be at no loss as to what was in lyrical currency or what suited the popular taste. It will not do to assume that a type of ballad verse, the Child type, existed among the folk long before verse of its rhyming lyrical pattern, a new mediæval type, makes its appearance in the lyric in general. The folk are more likely to have adhered to the old alliterative verse with its dual movement long after it had lost popularity in higher circles than they are to have invented new rhyming forms before these appear from professional hands.

\section{II}

\section{Some Ballad Affiliations}

If ballad literature began with the religious ballads of the clericals, earlier ballads might be expected to show affinities with miracle plays and various types of scriptural and saints'-legend and other theological matter in verse and with religious lyrics. This they do show; and the resemblances are far stronger than they are to secular matter coming from the same early periods. Many of our existing Child ballads are on the border line between ballads and carols (French noëls), like The Bitter Withy, The Holy Well, The Cherry-Tree Carol, The Carnal and the Crane, 
so that they appear in illustrative collections of both types of verse. They are easily accessible in collections of both ballads and carols, are included in the Child collection, and they need not be reproduced here. They deserve either classification and make clear that the ballad and the religious carol may be related forms. There is also obvious relationship to the miracle plays and their cognates. The opening and the end of the thirteenth-century Harrowing of $\mathrm{Hell}^{10}$ exhibit ballad-like stanzas:-

Alle herkneth to me nou, A strif wolle y tellen ou of ihesu ant of sathan, tho ihesu wes to helle ygan ...

in godhed tok he then way that to helle gates lay.

The he come ther tho saide he asse $y$ shal nouthe telle the.

The Brome Abraham and Isaac is often suggestive of the ballad manner. It is familiar, and space need not be given to quotation from it. The ballads also show affinities to scriptural and saints'-legend matter in verse of narrative type. ${ }^{11}$

${ }^{10}$ Ed. all versions, W. H. Hulme, E. E. T. S., Extra Series, 100 (1907).

${ }^{11}$ Compare in The Minor Pieces of the Vernon Manuscript, vol. I, ed. Horstmann, E. E. T. S., No. 98 (1892) "The Miracles of Our Lady," p. 138, "The Saving of Crotey City," "The Child Slain by the Jews," "A Jew Boy in an Oven," etc., the opening of "The Visions of Seynt Poul wan he was rapt into Paradys," etc.; vol. II, ed. Furnivall (1901), "Susannah, or Seemly Susan," p. 626; and in the Sloane Manuscript 2593, "St. Nicholas and Three Maidens" and "Nowel, Mary moder cum and se," etc. Also many pieces in Ms. Balliol 354.

The religious tag stanzas at the end of older ballads-often dropped in later texts-account for themselves better if emerging from ecclesiastical influence than if emerging from the purely secular minstrelsy condemned for its influence by the church. Examples are 
Among the earlier minstrels, the dramatic instinct brought impersonation in which monologue and dialogue were given dramatically, by one individual, perhaps sometimes in special costume. There are religious pieces like the thirteenth-century Harrowing of Hell, or like Judas (it may well be) or St. Stephen and Herod, which suggest that they were to be given dramatically. The dramatic element is strong in ballads and also in carols and in many religious poems intended to be given for instruction.

Most striking, however, is the fact that in lyrical quality and style ${ }^{12}$ the closest affinities of the ballads of the preElizabethan period seem to be with carols and with religious songs. It is in manuscripts containing religious lyrical pieces that some of the oldest ballads and the nearest approaches to ballads are found. ${ }^{13}$ Impose the lyrical

the endings of The Battle of Otterbourne or The Hunting of the Cheviot:

Now let us all for the Perssy praye

to Jhesu most of myght,

To bryng hys sowlle to the blysse of heven

for he was a gentyll knight.

Or-

Jhesue Crist our balys bete, and to the blys vs brynge.

Thus was the hountyng of the Chivyat:

God send vs alle good endyng.

But this is uncertain ground. Such passages appear in the romances, as Sir Orpheo, as well as in sermons, like the old Kentish sermons of the thirteenth century. In the Danish ballads, Steenstrup thinks these tag stanzas a sign of lateness.

${ }^{12}$ The influence of the song of the early church has often been pointed out. "The lyric art, it is hardly too much to say," decTares Rhys, "was in English kept alive for nearly three centuries by the hymns of the monks and lay brothers" (Lyric Poetry [1913], p. 19).

${ }^{13}$ The English religious lyric of the Middle Ages far exceeds in quantity that of secular verse and it appears much earlier. The thirteenth and fourteenth centuries afford many specimens. That many were written in this period is clear from the number which 
quality of some types of carols upon a variety of narrative themes, or situation themes, and the type of ballad is reached which emerges in such abundance in the later sixteenth and earlier seventeenth centuries. The early Tudor period was one of great musical impulse, and the singing of ballads to melodies might then have won in favor over the older recital. Be this as it may, it is in the sixteenth century that the ballad texts which remain to us ${ }^{14}$ first assume the lyrical refrains that both the religious and the older secular carols exhibited earlier. The Sloane manuscript of the middle of the fifteenth century is the richest in ballads or ballad-like pieces before the Percy manuscript, and it contains mainly religious and moral songs, three in Latin, nearly one hundred with Latin refrains, and numerous Christmas carols. The earliest approaches to the song manner of ballads which remain to us are ecclesiastical.

There is lyrical or structural repetition in the ballad manner in the early fourteenth-century Song of the Incarnation:- 15

I syng of a mayden that is makeles;

Kyng of alle kynges to here sone che ches.

he cam also stylle ther his moder was, as dew in aprylle that fallyt on the gras.

yet remain to us. Before the thirteenth century, most religious lyrics were in Latin.

${ }^{14}$ With the possible exception of Robin and Gandeleyn. I have not been able to see the Harvard doctorate thesis of J. H. Boynton, Studies in the English Ballad Refrain, with a Collection of Ballad and Early Song Refrains (1897), for the thesis remained unpublished.

${ }^{15}$ From the Sloane Ms. 2593. And compare $A$ Song of Joseph and Mary in a manuscript of the Advocate's Library, Edinburgh, dated 1372, first printed by Professor Carleton F. Brown, Selections from old and Middle English (1918); also Lamentacio Dolorosa and Lullaby to the Infant Jesus, first printed (from the same manuscript) by Professor Brown. 
he cam also stylle to his moderes bowr as dew in aprille that fallyt on the flour.

he cam also stylle ther his moder lay, as dew in aprille that fallyt on the spray.

moder \& maydyn was neuer non but che; wel may swych a lady godes moder be.

There is something of the lyrical quality of the ballads in- 16

Adam lay y-boundyn, boundyn in a bond fowr thousand wynter thowt he not to long and all was for an appil, an appil that he took. ...

and in carols like "A new yer, a new yer, a chyld was iborn," and in many others. And surely there are close ballad affinities to be found in a song like this, written down in the reign of Henry VIII:- 17

\section{Lully lulley}

The faucon hath stolen my make away.

1. He bare him up, he bare him down,

He bare him into an orchard brown. Lully, etc.

2. In that orchard there was an hall, Which was hanged with purpill and pall. Lully, etc.

3. And in that hall there was a bed, It was hanged with gold so red. Lully, etc.

4. And in that bed there lith a knight, His woundes bleding day and night. Lully, etc.

${ }^{16}$ Bernhard Fehr, Die Lieder der HS. Sloane 2593, Archiv, vol. cIx, p. 51. Compare also some of the short religious pieces edited by Furnivall, E. E. T. S., vol. Xv (1866), as "Christ Comes," p. 259, from the Harleian Ms. 7322.

${ }^{17}$ MS. Balliol 354. Richard Hill's Commonplace Book, E. E. T. S., Extra Series 101 (1907). This book contains many sacred songs and carols and many moral didactic and historical pieces and a few worldly and humorous pieces. It abounds in approaches to the ballad manner. 
5. By that bedside kneleth a may, And she wepeth both night and day. Lully, etc.

6. And by that bed side there stondeth a stone, Corpus Christi wreten there on. Lully, etc.

( Lully lulley, lully lulley

The faucon hath borne my make away.)

This song with a burden like a ballad, or like that of a Christmas carol, was interpreted by Professor Flügel as the story of Christ's Passion, and his interpretation was borne out by a discovery of a modern traditional carol by F. Sidgwick. ${ }^{18}$ The song is a religious song. The tendency in criticism has been to associate the ballads with older heroic poetry or with romance, or with dance songs; but comparison will show that, in the texts earliest to appear, a closer connection in lyrical quality and in the use of refrains and repetition is afforded by the religious lyrics. The closest approaches which one finds to the ballad manner are the religious pieces like those in the Sloane-and the Hill manuscripts.

Lyrical narratives in couplet and quatrain form are admitted as ballads. If the three-line carol stave - which dropped from use because a less suitable form for narrative verse ${ }^{19}$-were recognized also, such pieces as the following narrative carol ${ }^{20}$ might be termed ballads. Both the couplet and the carol stave had wide lyrical popularity earlier than the quatrain.

${ }^{18}$ See Notes and Queries, 1905. Christ is referred to again and again as a "knight" in many religious songs from the Love Rune of Thomas de Hales onward.

19 The iteration of triple rhyme brings monotony and checks the speed of the narrative. Just as with the ballad, so with the popular hymn stanza, the three-line form was replaced by the quatrain.

${ }^{20}$ Ms. Balliol 354. Richard Hill's Commonplace Book. Ed. Dyboski, E. E. T. S., Extra Series, 101 (1907), p. 1. 
Owt of the est a sterre shon bright

For to shew thre kingis light,

Which had ferre traveled day \& nyght

To seke that lord that all hath sent.

Therof hard kyng Herode anon,

That III kingis shuld cum thorow his regyon,

To seke a child that pere had non,

And after them sone he sent.

Kyng Herode cried to them on hye:

"Ye go to seke a child truly;

Go forth \& cum agayn me by, \& tell me wher that he is lent."

Forth they went by the sterres leme, Till they com to mery Bethlehem;

Ther they fond that swet barn-teme That sith for vs his blode hath spent.

Balthasar kneled first a down \& said: "Hayll, Kyng, most of renown, And of all kyngis thou berist the crown, Therfor with gold I the present."

Melchior kneled down in that stede \& said: "Hayll, Lord, in they pryest-hede. Receyve ensence to thy manhede, I brynge it with a good entent."

Jasper kneled down in that stede \& said: "Hayll, Lord, in thy knyghthede, I offer the myrre to thy godhede, For thou art he that all hath sent."

Now lordis \& ladys in riche aray, Lyfte vp your hartis vpon this day, \& ever to God lett vs pray, That on the rode was rent.

The following from the Hill manuscript ${ }^{21}$ is not included or mentioned by Professor Child, yet, if instead of being narrated in the first person like a few of the ballads

${ }^{21}$ Ed. Dyboski, E. E. T. S., 101, p. 40. 
it were narrated in the third, like most of them, and if it were in couplet or in the more usual quatrain form instead of in monorhyme quatrains, who would hesitate to classify it as a ballad? It is clearly akin to the Judas which is so classified.

"O my harte is wo!" Mary she sayd so,

"For to se my dere son dye; \& sonnes haue I no mo."

"Whan that my swete son was XXXti wynter old, Than the traytor Judas wexed very bold;

For XXXti platis of money, his master he had sold;

But whan I it wyst, lord my hart was cold.

$\mathrm{O}$, my hart is woo!" [Mary, she sayd so,

"For to se my dere son dye; \& sonnes haue I no mo."]

"Vpon Shere Thursday than truly it was,

On my sonnes deth that Judas did on passe;

Many were the fals Jewes that folowed hym by trace, \& ther, beffore them all, he kyssed my sonnes face.

0 , my hart is wo!" [Mary, she sayd so,

"For to se my dere son dye; \& sonnes haue I no mo."]

"My son, beffore Pilat browght was he;

\& Peter said III tymes he knew hym not perde.

Pylat said vnto the Jewes: 'What say ye?'

Than they cried with on voys: 'Crucyfyge!'

0 , my hart is woo!" [Mary, she sayd so,

"For to se my dere son dye; \& sonnes haue I no mo."]

"On Good Friday at the mownt of Caluary

My son was don on the crosse, nayled with naylis III, Of all the frendis that he had, neuer on could he see,

But jentill the evangelist, that still stode hym by.

0 , my hart is woo!" [Mary, she sayd so,

"For to se my dere son dye; \& sonnes haue I no mo."]

"Thowgh I were sorowfull, no man haue at yt wonder; for howge was the erth-quak, horyble was the thonder; I loked on my swet son on the cross that stod vnder;

Than cam Lungeus with a spere \& clift his hart in sonder.

0 , my hart is woo!" [Mary, she sayd so,

"For to se my dere son dye; \& sonnes haue I no mo."] 
Its relation to the Judas is seen when the two are read side by side. The latter opens :-

Hit wes upon a Scerethorsday that vre louerd aros;

Ful milde were the wordes he spec to Iudas.

"Iudas, thou most to Iurselem, oure mete for to bugge;

Thritti platen of seluer thou bere up othi ruggi. .."

It is a somewhat arbitrary distinction which admits the second piece as a ballad and denies to the more lyrical one such classification. The pieces might well have emerged from the same types of authorship and audience. The thirteenth-century ballad of The Twelfth Night in the same Trinity College manuscript and in the same handwriting as the Judas, but in more elaborate stanza form, has already been mentioned. It opens :-

Wolle ye iheren of twelte day, wou the present was ibroust.

In to betlem ther iesus lay, ther thre kinges him habbet isoust.

a sterre wiset hem the wey, suc nas neuer non iwroust,

ne werede he nouther fou ne grey, the louerd that us alle hauet iwroust.

It seems difficult to believe that such religious pieces as the Judas and the St. Stephen and Herod represent a type to be developed by the addition of narrative from the secular carol or dance song, as suggested by Professor Ker. ${ }^{22}$ They owe much to religious songs. Perhaps if we note that refrains of both types, of secular dance songs and of religious songs, precede the appearance of refrains in the English and Scottish ballads (these appear mostly in the late sixteenth and the seventeenth centuries); if we recognize as most essential in the ballads a narrative element to be presented in the manner of the religious pieces; and if we impose the somewhat arbitrary condition of

${ }^{22}$ English Literature: Mediceval (1912). Home University Library edition, p. 159. 
couplet or quatrain form, barring the three-line carol stave, quatrain monorhyme, and related forms, we are on fairly safe ground. Certainly it seems quite unnecessary to retain the hypothesis of connection with dance-song origin, whether aristocratic, like the secular carols of Chaucer's time, or of the folk. Behind the earliest ballad texts which remain to us one finds no traces of affiliation with secular dance songs.

The handling of the refrain is striking in the following piece, also from the Hill manuscript, which, except for its brevity and for our traditional rejection of narratives in carol-stave form, we should classify as a ballad. ${ }^{23}$

The Stoning of St. Stephen

Whan seynt Stevyn was at Jeruzalem, Godis lawes he loved to lerne;

That made the Jewes to cry so clere \& clen, Lapidaverunt Stephanum,

Nowe syng we both all \& sum:

Lapidauerunt Stephanum.

The Jewes that were both false \& fell, Agaynst seynt Stephyn they were cruell, Hym to sle they made gret yell, \& lapidaverunt Stephanum

Nowe syng we, etc.

They pullid hym with-owt the town, \& then he mekely kneled down, While the Jewes crakkyd his crown, Quia lapidaverunt Stephanum.

Nowe syng we, etc.

Gret stones \& bones at hym they caste, Veynes \& bones of hym they braste, \& they killed hym at the laste, Quia lapidaverunt Stephanum. Nowe syng we, etc.

${ }^{23}$ E. E. T. S., 101 (1907), p. 32. The Stoning of St. Stephen is not mentioned by Professor Child. Both the St. Stephen pieces are probably to be classed as St. Stephen day songs or carols. 
Pray we all that now be here,

Vnto seynt Stephyn, that marter clere,

To save vs all from the fendis fere.

Lapidauerunt Stephanum.

Nowe syng we, etc.

It arrays itself alongside St. Stephen and Herod. The two lyrics, one adjudged to be a ballad, the other not to be one, are at least not so different in type as to make necessary the hypothesis of an utterly different mode of origin for the second. The Stoning of St. Stephen is the more lyrical of the two narratives and, unlike the earlier piece, it is provided with a refrain.

The following affords yet another illustration of an ecclesiastical, or semi-ecclesiastical, narrative song, from the period when Child ballads were not yet abundant. ${ }^{24}$

The Murder of Thomas a Beket

Lystyn, lordyngis both gret \& small, I will you tell a wonder tale, Howe holy chirch was browght in bale Cum magna iniuria.

A, a, a, a nunc gaudet ecclesia.

The grettest clark in this londe, Thomas of Canturbury, I vnderstonde, Slayn he was with wykyd honde, Malorum potencia.

A, a, a, a nunc gaudet ecclesia.

The knyghtis were sent from Harry the kynge, That day they dide a wykid thynge,

Wykyd men, with-owt lessynge, Per regis imperia.

A, a, a, a nunc gaudet ecclesia.

They sowght the bisshop all a-bowt, With-in his place, and with-owt, Of Jhesu Crist they had no dowght

Per sua malicia.

A, a, a, a nunc gaudet ecclesia.

${ }^{24}$ Balliol Ms. 354. The triple rhyme stanza of these ecclesiastical ballads appears also in Miracle plays, e. g., the Chester Noah's Flood. 
They opened ther mowthes wonderly wide, \& spake to hym with myche pryde:

"Traytor, here thow shalt abide, Ferens mortis tedia."

A, a, a, a nunc gaudet ecclesia.

Beffore the auter he kneled down, \& than they pared his crown, \& stered his braynes $v p$ so down, Optans celi gawdia.

A, a, a, a nunc gaudet ecclesia.

Recognition of song-narratives in carol stave, as well as those in couplet and quatrain form, would admit this piece also among ballads.

\section{III}

\section{Ballads and Clericals}

Clericals are known to have composed and sung religious lyrics; but an alternative hypothesis from that of direct ecclesiastical creation is that a lyric type successfully developed by minstrels, namely the song-story-existing alongside the songs of eulogy, of derision, the love songs, and other matter which they had in stock for entertainmentwas adopted and made use of for its own ends by the church. There would be abundant parallels for such a taking over. Ritson ${ }^{25}$ speaks of the utilization of popular airs by the Methodists of his day, much as they had been utilized earlier by the Puritans. The practice was not unknown to the evangelists Moody and Sankey and is not extinct among revivalists of the present time. Sumer is $i$ cumen in of the thirteenth century perhaps owes its preservation to the religious words written below the secular ones in the manuscript which has come down to us, and

${ }^{25}$ Dissertation on Ancient Songs and Music, prefixed to Ancient Songs and Ballads. Vol. I (ed. of 1829), p. lxxviii. 
there are other examples in old manuscripts of religious adaptation of secular lyrics. To find illustration farther back, Ealdhelm is described by William of Malmesbury ${ }^{26}$ as sometimes standing in gleeman's garb on a bridge and inserting words of scriptural content into his lighter songs -an early example of the connection between the church and songs for the common folk. After the Conquest, with the coming of a new type of song, the employment of the short recited tale or of the sung story for popularizing religious material might well have produced pieces like the thirteenth-century Judas or the later St. Stephen and Herod or Inter Diabolus et Virgo. If the modes of the church were often utilized for secular poetry, the contrary tendency, the adoption of what was popular by the church, is also marked. The great days of the minstrels were the eleventh, twelfth, and thirteenth centuries, and the days of their break-up the fifteenth and the sixteenth centuries. Warton thought that "some of our greater monasteries kept minstrels of their own in regular pay." 27 The class of minstrels indicated by Thomas de Cabham, a thirteenth-century archbishop of Canterbury, as to be tolerated while other classes deserved to be condemned, was the class which sang the deeds of princes and the lives of saints. $^{28}$ When minstrels had ecclesiastical audiences, re-

${ }^{26}$ De Gestis Pontificum Anglorum. Chronicles and Memorials of Great Britain and Ireland during the Middle Ages. Published under the direction of the Master of the Rolls, 1858-99, p. 336.

${ }^{27}$ There are many records of payments to minstrels extant in account books of Durham Priory, from the thirteenth century onward, and from Maxtoke and Thetford Priories from the fifteenth century.

${ }^{28}$ Penitential, printed by B. Hauréau, Notices et Extraits de Manuscrits, xxiv, ii, 284, from Bib. Nat. Lat. 3218 and 3529. Sunt autem alii, qui dicuntur ioculatores, qui cantant gesta principum et vitam sanctorum, et faciunt solatia hominibus vel in aegritudinibus 
ligious matter or national or heroic matter might come from them appropriately. A testimony remains concerning the songs of a minstrel Herbert before the prior of St. Swithin's when he entertained his bishop at Winchester in the fourteenth century (1338), and they were songs of Colbrand (Guy of Warwick) and of the deliverance by miracle of Queen Emma. ${ }^{29}$ From the fifteenth century is a record of a song of the early Christian legend of the Seven Sleepers of Ephesus given at an Epiphany entertainment at Bicester in $1432 .^{30}$ These may not have been ballads, but they fall in the ballad period and their material is of the type, the deeds of princes and the lives of saints and martyrs, which was countenanced by de Cabham.

A piece of first-hand evidence concerning the value of the harper and his harp to a discriminating prelate is related by Robert Manning of Brunne in an account of Robert Grosseteste, Bishop of Lincoln, who died in 1253. Bishop Grosseteste wrote in English as well as Latin, translating the allegorical Castel of Love into English for the sake of the ignorant. He recognized that the common people had to be reached in their own tongue. Robert Manning's testimony is as follows: ${ }^{31}$
$\mathrm{Y}$ shall you tell as I have herd
Of the bysshop seynt Roberd,
His toname is Grosteste
Of Lyncolne, so seyth the geste,
He lovede moche to here the harpe,
For mans witte yt makyth sharpe.

suis vel in angustiis ... et non faciunt etc. ... Si autuem non faciunt talia, sed cantant in instrumentis suis gesta principum et alia talia utilia ut faciant solatia hominibus, sicut supradictum est, bene possunt sustineri tales, sicut ait Alexander papa.

${ }^{29}$ See Warton, History of English Poetry, ed. of 1840, pp. 81, 82.

${ }^{30}$ Kennet, Parochial Antiquities (1695), ed. of 1818.

${ }^{31}$ Handlyng Synne, ed. F. J. Furnivall, E. E. T. S., 119. 
Next hys chamber, beside hys study, Hys harper's chamber was fast therby. Many tymes, by nightes and dayes, He hadde solace of notes and layes, One askede hem onys resun why He hadde delyte in mynstrelsy? $\mathrm{He}$ answerde hym on thys manere Why he helde the harper so dere. The virtu of the harp, thurgh skyle and ryght Wyll destrye the fendys myght; And to the cros by gode skylle Ys the harp lykened weyl ... Tharefore, gode men, ye shall lere When ye any gleman here, To worshepe God at your power, As Davyd seyth in the sauter. Yn harpe, yn tabour, and symphan gle Worship God in trumpes and sautre: Yn cordes, yn organes, and belles ringyng, Yn all these worship the hevene kyng. Yf ye do thus, $y$ sey hardly, Ye mow here youre mynstralsy.

The alternative possibilities (granting that religious ballads are an early type) are: that short narrative lyrics on ecclesiastical themes emerged directly from clericals and that the type was later secularized; or that they emerged from the minstrels, and ecclesiastics availed themselves of the type; or that minstrels were solely responsible for the early religious ballads, composing them for audiences for whom they were especially suitable. But when lingering over these hypotheses, one is inclined to give the church a greater share of responsibility for the earliest ballads than the third hypothesis assumes.

If the earliest mediæval ballads, meaning by ballads lyrical stories of the type collected by Professor Child, were contemporaneously on both religious and heroic subjects, it is chance, or else the interest of ecclesiastics, that has preserved for us specimens of the one type and not of 
the other. If the heroic type, chronicle or legendary, was as early as the religious, early examples have not remained to show it. Against the hypothesis of contemporaneousness is the circumstance that songs of all other kinds, minstrel and popular, satires, eulogies of princes and heroes, songs of victories, love songs, songs of disparagement or derision, humorous songs, drinking songs, and the like, have descended to us from the Middle Ages. If ballads of the heroic type existed early, they should have appeared at least as early as the thirteenth century. The wish to impress sacred story may well have afforded the impulse to present such narratives in a short lyrical way, and the presence of narrative is the fundamental differentia, the quality distinguishing it from other folk-song, of the ballad as a lyric type.

A refrain is not present in the earliest ballad texts nor in the fifteenth-century ballads, ${ }^{32}$ including the Robin Hood pieces. Refrains do not appear in ballads until the sixteenth century, though they are frequent in early lyrics of other types. Moreover, they are sufficiently accounted for in the proportion of ballads in which they are present (not more than a fourth) by the fact that the ballads were sung. Hymns and carols and many love songs have refrains, and the ballad refrains were handled on the whole in their way. They do not resemble the fundamental iterative lines of dance songs, around which the latter songs as a class are built. ${ }^{33}$ Ballad refrains are added from the outside and are not stable even for the same text, while the

${ }^{32}$ Unless in Robin and Gandeleyn. If a refrain is present in this ballad it is extraneous to the stanza structure, not part of it. The stanzas of the ballad so vary in form and length as to make them seem more suitable for recital than for singing.

${ }^{*}$ See "The Ballad and the Dance," Publications of the Modern Language Association, vol. xxxIv, p. 360. 
refrain is the most identifying feature of the average traditional dance song. It is well established that the earliest mediaeval dance songs were not ballads; though the latter came to be used occasionally as dance songs, consistently as such in Denmark. The fundamental characteristic of ballads, the point of departure for their differentiation as a lyric type, would be their presentation of characters and story in a lyrical way, suitable for short recital or for song. It would not be the presence of a refrain, nor of incremental repetition, nor parallelism of line structure; for both are often absent from ballads and often present in other types of folk-song. A " situation" mode of narration is not perhaps fundamental, but such a mode would be natural in a lyric to be recited dramatically like the Judas perhaps, or like St. Stephen and Herod; or it might be developed, like repetition and parallelism, in traditional preservation. Ballad creation has for its motivating impulse the circumstance that characters and their story are to be brought before hearers, not in a narrative to be read, but briefly and memorably and dramatically in a recitational or song way. Only stories which lend themselves well to such handling are eligible material.

It is possible that very widespread diffusion for the ballads, especially for the secular ballads, their composition in quantity and their popular currency, may have come later than is generally assumed. They cannot have been very abundant when the makers of the Sloane Ms. 2593 and the Balliol ms. 354 made their collections. These men obviously had a taste for popular verse, yet compared to their display of related types of folk-verse, of approaches to ballads, their showing of ballads proper is meager. Had many ballads of the Child type been in general circulation in Southern England before the Elizabethan period, had this type of verse been so recognized, so distinctive and 
current as it was in the later sixteenth and the seventeenth centuries, the makers of these, like the makers of later manuscript books, might have been expected to give proportionate space to ballads in their pages.

The number of early religious ballads remaining is somewhat slender, too slender for a very solid structure to be based upon them; but their evidence is the most authentic that we have. The subject of ballad origins may well be re-examined from the angle of approach which these, our earliest ballad texts, suggest. The species next to fix attention upon itself is the outlaw ballad of the fifteenth and early sixteenth centuries; but the outlaw ballads come too late for dependable significance. Some were plainly to be recited ${ }^{34}$ in general they lack the refrain element; and they afford no help in explaining the origin of the lyrical species. The suggestion which relates the early ballads to the religious, not the secular, carols as a type of folk-song, which assumes ecclesiastical emergence for the ballads prior to their minstrel popularity, or else early adoption by ecclesiastics of a new minstrel lyric type, has the distinction of novelty, whether or not it seem likely. And it is based on fact, not conjecture. The possibility that ballad literature began with clericals deserves to be taken into account, alongside the hypotheses of ballad origin which have been brought forward in the past.

Few having knowledge of the shifting types and styles of popular song would maintain that the folk-songs, the dance songs, if you will, of the Anglo-Saxons before the Norman Conquest were of the structure and type of the Child ballads. The patterns which these exhibit arose later. Nor were the old heroic lyrics of the Germanic

${ }^{34}$ See the testimony concerning " robene hude and litil ihone" and the tale of the "zong tamlene" listed in The Complaynt of Scotland, 1549. Edited by J. A. H. Murray, E. E. T. S. (1872), vol. I, p. 63. 
peoples, whether narratives or not, of the type of the Child ballads. In the hypothesis that mediæval ballad literature emerged under the influence of clericals, or in something like it, may perhaps be found the explanation best satisfying all the conditions. Examination is desirable, from this angle of approach, of the early lyrical verse of other leading European peoples. The ballad documents of Continental literatures are no earlier than the English, if so early; but the more the available evidence, the better for the investigator. A scrutiny of them might lend support to the suggestions of this paper, or it might contradict them, or it might bring light from some unexpected source.

Louise Pound. 